\title{
A Review of the Impact of Reforms on Investment in Tanzania's Power Sector
}

\author{
James Andilile*, Saganga Mussa Kapaya \\ Business Management, Open University of Tanzania, Dar es Salaam, Tanzania \\ Email: ^andilile@gmail.com, Kapaya.saganga@gmail.com
}

How to cite this paper: Andilile, J., \& Kapaya, S. M. (2021). A Review of the Impact of Reforms on Investment in Tanzania's Power Sector. Open Journal of Business and Management, 9, 2834-2853.

https://doi.org/10.4236/ojbm.2021.96158

Received: September 7, 2021

Accepted: November 5, 2021

Published: November 8, 2021

Copyright $\odot 2021$ by author(s) and Scientific Research Publishing Inc. This work is licensed under the Creative Commons Attribution International License (CC BY 4.0).

http://creativecommons.org/licenses/by/4.0/

(c) (i) Open Access

\begin{abstract}
This study investigates the impact of reforms on investment in Tanzania's power sector. The data from 1989 to 2020 were collected and analyzed using the Autoregressive Distributed Lag Model (ARDL) and paired-sample t-tests. It was determined that, as a result of government sponsorship, capacity growth and electricity connectivity as a measure of investment had increased modestly after reforms. The results appear to contradict laissez-faire and privatization theories, which attributed the increase primarily to private investment. The liberalization law, competition, and commercialization as the reform policies were found to be statistically significant and positively affecting investment. Thus, regardless of ownership form, we recommend that the government prioritize these reform policies for improved investment in the sector. Second, to bridge the infrastructure deficit and ensure long-term secure supply, both the public and private sectors should be encouraged to make investments. The value of these findings extends beyond Tanzania to other countries that are struggling to formulate or reformulate their reform programs as it suggests that if prudently managed the public sector can as well improve investment.
\end{abstract}

\section{Keywords}

Investment, Capacity Growth, Electricity Connectivity, Reforms

\section{Background}

In Tanzania (the then Tanganyika) electricity was introduced by Germans in 1908. In 1931, the public electric facilities were privatized to Tanganyika Electric Supply Company Ltd and Dar es Salaam and District Electric Supply Company Ltd. To overcome the private sector's limitations in increasing access, in 1964 the two companies were merged to form the incumbent Tanzania Electric Supply Company Ltd (TANESCO). In 1975 the government acquired all of TANESCO's 
shares, transforming the company into an effective state monopoly. The move was premised on the assertion that the power sector is too important socially, politically, and economically to be left to the private sector. Until the early 1980s, the sector performed well, and the government was the primary source of funding.

Nevertheless, by the late 1980s, investment in the power sector began to deteriorate due to the government's inability to fund the sector sustainably. The challenge was triggered among others by the 1970s economic crisis, the collapse of the East African Community, and the Tanzania-Uganda war. By the 1990s the power system in Tanzania had become dysfunctional and unable to meet the rapid demand expansion for the rising population and the economy. The supply was persistently unstable, inadequate, and insecure endangering the socio-economic fabric of the nation as it led to considerable economic and welfare loss (Godinho \& Eberhard, 2018). Thus, after a long period of state monopoly, in the 1990s the government embarked on the sectoral institutional and structural reforms.

Like most reforming countries, Tanzania adopted a standard reform model which entails the introduction of liberalization law, independent regulation, independent power producers, unbundling, corporatization, commercialization, energy fund, privatization, and competition (see Lee \& Usman, 2018; Yang \& Urpelainen, 2019). The reforms were underpinned by market-oriented theories such as the laissez-faire and privatization theories. These theories combined contend that private ownership and competition improve performance and investment in the sector. With many electricity buyers and sellers, the new market structure was anticipated to mimic a perfectly competitive market. The fusion of market mechanisms in the sector was thus hoped to jump-start the performance and maximize societal welfare (Lee \& Usman, 2018; Gratwick \& Eberhard, 2008). It was also thought that increased private investment would help to close service delivery gaps and relieve pressure on government resources (World Bank, 2017).

In 1992, Tanzania promulgated the first national energy policy to liberalize the sector. Except for unbundling, Tanzania has attempted to implement almost all elements of the standard reform model (see Appendix 1). Notwithstanding the promises that the reforms would address capacity shortages and investment constraints, it appears that the results have fallen short of expectations. It is thus generally hypothesized that the reforms in Tanzania did not statistically significantly affect investment positively. This study attempts to explore the extent to which the reforms had improved investment in Tanzania and whether the surge (if any) can be directly linked to the reforms. The remaining sections are organized as follows. Section 2 presents the experience from reforming countries; Section 3 articulates the research methodology whilst Section 4 discusses the findings of the study. Section 5 concludes the study by synthesizing reform policy recommendations and section 6 is an acknowledgement. 


\section{Reforms' Experience}

In the 1990s, an insecure power supply was one of the vexing problems that faced nearly most developing countries. The reforms were mooted to solve this problem by promoting private investment and competition. In most countries, attracting private investment was a top priority of reforms and thus perhaps a more reliable measure of the reforms' success (Jamasb, Mota, Newberry, \& Pollitt, 2005; Bergara et al., 1998). Theoretically, in most developing countries the reforms were hoped to fix the problem of underinvestment in the sector. It remains unclear the extent to which these initiatives have solved this challenge in Tanzania. Several studies have so far attempted to investigate the effect of reforms on investment but with varying results.

In the context of capacity growth, Balza et al. (2013) and Jamasb et al. (2005) for instance found that in Pakistan, Chile, and Argentina respectively the reforms led to an increase in installed capacity. Applying Fixed Effect (FE) and Random Effects (RE) Models on data over 35 years from 55 developed and developing countries, Erdogdu (2014) learned that the reforms led to self-sufficiency in supply. In contrast, Tankha (2017) and Quiggin (2014) determined that in Brazil and Australia respectively, privatization and liberalization laws did not boost private investment leading to severe service quality problems. Deploying FE Model for OECD countries, Parker et al. (2002) realized that privatization and an efficient regulation increase generation capacity and lead to higher labour productivity. In contrast using the FE Model on a dataset from 1985 to 2000 from 51 developing countries, Zhang, Parker and Kirkpatrick (2005) established that privatization and regulation on their own do not increase the capacity or improve labour productivity. Aminu et al. (2014) and Ashong (2010) also revealed that in Nigeria and Ghana respectively the reforms did not increase generation capacity but only facilitated a transfer of people's collective wealth to a few elites.

In Oman, Albadi (2017) discovered a lack of sustainable capacity growth and improvement in the energy mix after the reforms. Using the FE Model on a dataset from 1980 to 2001 from 28 developing countries, Cubin and Stern (2006) ascertained countries with strong regulatory systems attract investment sustainably at a lower cost and. Similarly, Bergara et al. (1998), links an increase in private investment to the existence of credible institutional factors. In Australia Quiggin (2014) spotted that the reforms did not promote efficient investment and suggest that the only sensible way to address critical infrastructure crises is through the public sector. In support of this stance, Hall and Nguyen (2017) discovered a significant growth in capacity and electricity access even in a predominantly publicly-owned sector.

After privatization in the UK, Victor and Heller (2008) saw a 25\% increase in generating capacity. Deploying the Generalized Least Squares Model (GLS) for data from 28 Latin American countries, Balza et al. (2013) determined that in Chile the installed capacity, labour productivity, service coverage, and profitabil- 
ity had improved after the reforms. Using the FE Model on a dataset from 1985 to 2000 from 51 developing countries Zhang et al. (2008) detected that privatization and regulation on their own do not increase capacity and labour productivity. Zhang et al. (2005) saw that the introduction of independent regulation and competition before privatization leads to higher electricity generation capacity.

One of the ultimate goals of the reforms in developing countries was to accelerate and deepen electricity connectivity particularly to the poor (Jamasb et al. 2014). Davies, Wright and Price (2006) therefore suggest that the success of the reforms, therefore, should be judged by the extent to which it benefits the poor. Studies such as Jamasb et al. (2005) uncovered that after the reforms the electricity connectivity in 115 sampled developing countries had increased. Equally, Nepal (2013) and Eberhard and Godinho (2017) noted that in Latin America, electricity connectivity had improved in the post reforms. In Chile, Fisher, Gutierrez and Serra (2004) noted that reforms led to a significant increase in access to electricity, especially in rural areas.

Studies (Bastos \& Abdala, 1996; Jamasb et al., 2005) also found that privatization in Chile and Argentina lead to a significant advance in service coverage and quality. Using OLS Model with data of over 32 years from 100 countries, Dertinger and Hirth (2019) uncovered that the reforms had increased electricity access, but did not solve the problems of the system losses. In developing countries studies (Cubbin \& Stern, 2006) attach the introduction of privatization, competition, high-quality regulatory governance, and liberalization law with increased generating capacity and service penetration. Applying the FE and RE Models on data from 1989 to 2009, the World Bank (2011) also determined a substantial increase in access to electricity following the introduction of independent regulation in 20 developing countries.

Surprisingly, Estache et al. (2009) associate the introduction of independent regulation in developing countries with the reduction in access rates. Likewise, Bhattacharyya (2006) and Sihag et al. (2007) discovered that in the State of Orissa in India the reform policies such as led to a decline in access rates. In Nigeria, Idris et al. (2013) saw a decline in electricity connectivity, especially that after the reforms access to electricity had declined especially to the poor. In Sub-Saharan Africa, the World Bank (2017) detected that after the reforms the connectivity did not increase significantly particularly in rural areas. In Kenya and Uganda, Karekezi and Kimani (2002) observed that the reforms did not improve access to electricity significantly, particularly to the poor rural.

Tanzania started the reforms in 1992. The initial studies however suggest that despite the reforms, the sector still suffers from infrastructure deficits, low access particularly in rural areas, and weak financial condition (World Bank, 2017). Similarly, the IMF (2016) attests that, despite concerted efforts to improve rural electrification, access to electricity in Tanzania still lags behind the low-income countries although in line with the average of East Africa. Jamasb et al. (2015) conclude that in most developing countries reforms have failed to correct the 
chronic challenges of underinvestment which leads to persistent sectoral underperformance.

The empirical findings above reveal mixed results demonstrating that there is no one size fits all reform model and that country-specific factors matter. This study sets a blueprint for evaluating the impact of reforms in Tanzania. Previous studies had some limitations that need to be addressed. From a theoretical standpoint, Sen et al. (2016) admit that so far there is no universal theory that guides the reforms. This study, therefore, adopted the laissez-faire and privatization theories both of which origin is accredited to Adam Smith (1776), who contend that private ownership and competition improve efficiency and maximize societal welfare. The self-interest entrenched in private ownership thus becomes the driving force for an economic agent to operate efficiently while competition turns out to be the regulator of economic activities. The theory is however challenged on the basis that even competitive markets are inherently imperfect and prone to failure due to externalities, monopolistic actions, and information asymmetry (Mayson, 2013).

The reforms were driven by the assumption that the public sector is inefficient because management pursues political goals rather than maximizing efficiency. It was hoped that privatization would improve performance by making the sector less subject to political opportunism (Lee \& Usman, 2018; Nepal \& Foster, 2015). So far however there is no conclusive theoretical consensus on the economic gains of reforms as recent international experience suggests that even in the highly liberalized markets, private ownership and competition are still limited leading countries to continue to suffer from supply crises (Govinda et al. 2015; Yang \& Urpelainen, 2019; Jamasb et al., 2016; Siami-Namini, 2017). This revelation widens the theoretical gap as it defeats the assertion that links change in ownership from public to private ownership with improved performance. This study attempts to bridge this gap by assessing the relevance of these theories to Tanzania.

Empirically, there is so far, no agreement about the economic benefits of reforms (Govinda et al., 2015; Jamasb et al., 2016; Yang \& Urpelainen, 2019). There is thus evidence gap as results from reforming countries are mixed. Methodologically, most of the previous studies were based on the Generalized Method of Moment models and a panel dataset. This study uses the time series dataset modelled using the recently developed Autoregressive Distributed Lag (ARDL) model. In Tanzania, it appears that the reforms have not significantly improved investment thus defeating the originally intended goal. Mwandosya (2013) indicates that despite the reforms, the outcomes in Tanzania are not well known. Scholars (Besant-Jones, 2006; Lee \& Usman, 2018) suggest that the best way to assess the impact of reforms is at the country level. Our observation is that there is still considerable uncertainty about the impact of reforms on investment, necessitating more research. We thus attempted to fill this gap by quantitatively studying the impact of reforms in Tanzania using capacity growth and electricity 
connectivity as proxy measures of investment.

Overall, this paper seeks to answer the question of whether the reforms in Tanzania have increased investment and whether the surge (if any) can be directly related to the reforms. To the best of our knowledge, such analyses are very limited in Tanzania. This study thus presents the theoretical and empirical evidence that unravel the existing hiatus between the theory and practice of the reforms by reflecting on Tanzania. The findings of this study will be of value to Tanzania and beyond in several ways. First, policy lessons will aid policymakers in reforming their power sectors with new and advanced knowledge about the reforms. Secondly, it will give scholars and researchers new insights and the dynamics of the reforms. Third, it will help the general public understand the progress and outcome of the reforms in Tanzania. The next section discusses the methodology deployed in this study.

\section{Data and Methodology}

We used data from 1989 to 2020 separated into pre (1989-2005) and post the reforms period 2006-2020). The year 2006 was used as the baseline for after the reforms as in Tanzania meaningful reforms only began when Energy and Water Utilities Regulatory Authority (EWURA) became operational in 2006. The year 2020 was the last year for which data were available at the time of research. To ensure data quality limited data sources with legal custodianship and mandates to publish them including TANESCO, Ministry of Energy, EWURA, National Audit Office, and National Bureau of Statistics were considered.

The paired sample t-test and ARDL model were deployed in the analysis. The paired sample t-test was used to measure whether there is a significant difference in mean values as computed by STATA 13 between pre and post reforms periods. The ARDL model was applied to determine causality effects and cointegration between variables. The model is suitable for small samples, addresses adequately the problems of autocorrelation and endogeneity among variables and is applied when the dependent variables are of the order I(1) and the rest of the variables are either $\mathrm{I}(1)$ or (0) or both. This model is analogous to those used in previous studies (Zhang et al., 2008; Polemis, 2016; Jamasb et al., 2016).

We performed the stationarity test and determined the appropriate lags using the Augmented Dickey-Fuller (ADF) Unit Root Tests and Akaike Information Criterion (AIC) respectively. The cointegration between variables was analyzed using the ARDL Bounds testing approach. The coefficients of variables, serial correlation, the function of form, normality and heteroscedasticity and parameters stability tests were both done using MICROFIT Software 5.5. The software is one of the most powerful menu-driven time-series econometric packages currently available with a range of diagnostic and non-nested tests that are not readily available in other packages.

Independent variables used conform to the standard reform model. Unbundling was excluded as is yet to be implemented in Tanzania. The IPP was blended 
into privatization as they occurred concurrently hence difficult to separate their effects. The independent variables were ranked between 0 and 4 depending on the level of progress from the ideal competitive market in line with Erdogdu (2013). The measurement variables were defined as follows:

Capacity Growth (CGt) reflects the investment in system expansion per annum to meet the growing demand. It is calculated by dividing the net change in the current year's installed capacity by the preceding year's total installed capacity. The increase means improvement.

Electricity Connectivity $(E C t)$ represents a proportion of the population connected to electricity. It is calculated by dividing the number of households connected to electricity or metered times the average number of persons per household by the total population. This study used 4.6 people per household in line with NBS (2020). The increase in connectivity implies improvement.

These variables were selected for several reasons. First, they were the main drivers of the reforms in most countries. Second, previous studies (Zhang et al., 2008; Kapika \& Eberhard, 2010; Wooders et al., 2014) used similar variables though in a piecemeal fashion. Third, they are consistent with the World Bank's (2009) indicators for measuring performance in SSA.

\section{Results and Discussion}

The study findings and discussions are founded on the ARDL and t-test results for capacity growth and electricity connectivity. The integration between variables was estimated using the F-Statistics for each performance indicator.

Table 1 suggests that the variables are integrated of order I(1) and become stationary at their first differences making the use of the ARDL Model plausible.

Table 1. ADF unit root tests results.

\begin{tabular}{|c|c|c|c|c|c|c|c|}
\hline \multirow[b]{2}{*}{ Variables } & \multicolumn{3}{|c|}{ At Level } & \multicolumn{4}{|c|}{ At First Difference } \\
\hline & $\begin{array}{c}\text { No Intercept, } \\
\text { No Trend }\end{array}$ & $\begin{array}{l}\text { Intercept, } \\
\text { No Trend }\end{array}$ & $\begin{array}{c}\text { Intercept, } \\
\text { Trend }\end{array}$ & $\begin{array}{c}\text { No Intercept, } \\
\text { No Trend }\end{array}$ & $\begin{array}{l}\text { Intercept, } \\
\text { No Trend }\end{array}$ & $\begin{array}{l}\text { Intercept, } \\
\text { Trend }\end{array}$ & Remarks \\
\hline CG & 1.78230 & -0.15063 & -2.74350 & -2.72500 & -3.58030 & -3.51040 & $\mathrm{I}(1)$ \\
\hline $\mathrm{EC}$ & 2.86850 & 1.79060 & -0.17108 & -1.16670 & -1.74360 & -2.21450 & $\mathrm{I}(1)$ \\
\hline LL & 0.81650 & 0.17310 & -1.51470 & -3.60560 & -3.93510 & -4.32620 & $\mathrm{I}(1)$ \\
\hline IR & 0.93831 & -0.47173 & -1.87810 & -3.60560 & -4.29200 & -4.19340 & $\mathrm{I}(1)$ \\
\hline $\mathrm{COM}$ & 1.03240 & -0.57934 & -3.57830 & -3.60560 & -4.29200 & -4.19340 & $\mathrm{I}(1)$ \\
\hline $\mathrm{EF}$ & 1.11630 & -0.00000 & -1.96380 & -2.54960 & -2.92170 & -2.88860 & $\mathrm{I}(1)$ \\
\hline PRIV & 0.43004 & -1.81300 & -1.29750 & -3.60560 & -3.98860 & -4.39630 & $\mathrm{I}(1)$ \\
\hline COMP & 0.43916 & -1.74190 & -1.40240 & -3.60560 & -3.98860 & -4.32100 & $\mathrm{I}(1)$ \\
\hline \multicolumn{2}{|c|}{ Critical Values } & -2.96650 & -3.57310 & & -2.97060 & -3.57960 & \\
\hline
\end{tabular}

Source: Author's Computation using MICROFIT 5.5. 
Table 2 shows that the integration results estimated using the F-Statistics for each performance indicator are fairly higher than the tabulated Critical Upper-Bounds values of 4.54 at a $99 \%$ level of significance. Thus, the null hypothesis of no co-integration among variables is rejected.

The paired sample t-test results in Table 3 indicate that there is a significant difference in mean values between before and after the reforms for capacity growth and electricity connectivity. In this case, the null hypothesis that the reforms had no statistically significant positive impact is rejected since $p<0.05$.

\subsection{Reforms and Capacity Growth}

Table 4 presents the ARDL results for the measurement variables. Our review revealed that after the reforms installed capacity had modestly increased. The liberalization law, commercialization, and competition are statistically significant affecting the capacity growth positively. The coefficient of the independent regulation is positive albeit not statistically significant whilst privatization policy is negative and statistically significant. The negative coefficient may be explained by the fact that most of the private sector's capacity was procured on an emergency basis during droughts and retired when hydrological conditions improved.

Limited private sector responsiveness in Tanzania can be associated with sectoral governance challenges manifested by weak institutional, regulatory, and legal frameworks, the trust deficit between the government and private sector-IPPs, and underpricing of the electric service. Godinho and Eberhard (2018) link the outcome to incomplete reforms evidenced by little progress in introducing and enforcing the reforms' best practice. From the results, we can therefore infer that though the capacity has grown after the reforms, the growth came from government funding rather than private capital. The most important policy

Table 2. Bound tests for cointegration.

\begin{tabular}{cccccc}
\hline Dependent Variable. & F-Statistic & [Prob.] & $\mathbf{9 9 \%}$ & & Conclusion \\
\hline & & & $\mathrm{I}(0)$ & $\mathrm{I}(1)$ & Cointegration \\
DCG & 8.0806 & {$[0.057]$} & 3.267 & 4.54 & Cointegration \\
\hline
\end{tabular}

Source: Author's Computations using MICROFIT 5.5.

Table 3. Paired samples test for dependent variables.

\begin{tabular}{|c|c|c|c|c|c|c|c|c|c|}
\hline \multirow{3}{*}{ Variables } & \multicolumn{5}{|c|}{ Paired Differences } & \multirow[t]{3}{*}{$\mathrm{T}$} & \multirow[t]{3}{*}{ Df } & \multirow{3}{*}{ Sign (2-tailed) } & \multirow{3}{*}{$\begin{array}{c}\text { Remarks } \\
\text { on Ho }\end{array}$} \\
\hline & \multirow{2}{*}{ Mean } & \multirow{2}{*}{$\begin{array}{c}\text { Std } \\
\text { Deviation }\end{array}$} & \multirow{2}{*}{$\begin{array}{l}\text { Std. Error } \\
\text { Mean }\end{array}$} & \multicolumn{2}{|c|}{ 95\% CI of the Difference } & & & & \\
\hline & & & & Lower & Upper & & & & \\
\hline PRE_CG - POST_CG & 778.00 & 1.55 & 42.90 & 684.00 & 871.00 & 18.12 & 12.00 & 0.0000 & Reject \\
\hline PRE_EC - POST_EC & 0.07 & 0.42 & 0.01 & 0.04 & 0.09 & 5.70 & 12.00 & 0.0000 & Reject \\
\hline
\end{tabular}

Note: $C G=$ Capacity growth, EC = Electricity connection. Source: Author's computations based on STATA 13. 
Table 4. ARDL output for capacity growth.

\begin{tabular}{|c|c|c|c|c|}
\hline \multicolumn{5}{|c|}{30 Observations used for estimation from 1989 to 2020} \\
\hline Regressor & Coefficient & Standard Error & T-Ratio & [Prob.] \\
\hline $\mathrm{CG}(-1)$ & 1.60190 & 0.28159 & 5.68860 & {$[0.000]^{\star * *}$} \\
\hline $\mathrm{CG}(-2)$ & -1.14360 & 0.34468 & -3.31790 & {$[0.007]^{* * *}$} \\
\hline LL & 244.66990 & 75.49570 & 3.24080 & {$[0.008]^{* * *}$} \\
\hline $\operatorname{LL}(-1)$ & -42.76770 & 37.31050 & -1.14380 & {$[0.277]$} \\
\hline IR & 117.81270 & 87.26670 & 1.35000 & {$[0.204]$} \\
\hline $\operatorname{IR}(-1)$ & 290.57970 & 70.13960 & 4.14290 & {$[0.002]^{* * *}$} \\
\hline $\mathrm{COM}$ & 142.59580 & 68.94530 & 2.06820 & {$[0.063]^{\star}$} \\
\hline $\operatorname{COM}(-1)$ & 96.70990 & 69.83840 & 1.38480 & {$[0.194]$} \\
\hline $\mathrm{EF}$ & -297.99510 & 84.66690 & -3.51960 & {$[0.005]^{* * *}$} \\
\hline $\mathrm{EF}(-1)$ & 33.19740 & 90.76470 & 0.36575 & {$[0.721]$} \\
\hline $\mathrm{EF}(-2)$ & -289.81060 & 103.69620 & -2.79480 & {$[0.017]^{\star *}$} \\
\hline PRIV & -301.21050 & 127.54170 & -2.36170 & {$[0.038]^{\star *}$} \\
\hline $\operatorname{PRIV}(-1)$ & -354.02510 & 134.14640 & -2.63910 & {$[0.023]^{\star *}$} \\
\hline $\operatorname{PRIV}(-2)$ & -410.08980 & 135.59030 & -3.02450 & {$[0.012]^{\star *}$} \\
\hline COMP & 373.79800 & 143.10000 & 2.61210 & {$[0.024]^{\star *}$} \\
\hline $\operatorname{COMP}(-1)$ & 242.69650 & 133.40820 & 1.81920 & {$[0.096]^{*}$} \\
\hline $\operatorname{COMP}(-2)$ & 325.33090 & 84.05260 & 3.87060 & {$[0.003]^{* * *}$} \\
\hline CONSTANT & 170.95250 & 82.07060 & 2.08300 & {$[0.061]^{*}$} \\
\hline R-Squared & 0.99305 & R-Bar-Squared & 0.9823 & \\
\hline S.E of Regression & 62.7752 & F-stat. F(17, 11) & & \\
\hline Mean of Dep. Var. & 899.579 & S.D of Dep.Var. & 471.821 & \\
\hline RSS & 433348 & Equat LL & -147.14 & \\
\hline AIC & -165.1401 & SBC & -177.45 & \\
\hline DW-statistic & 2.2869 & & & \\
\hline F-statistic & $95 \% \mathrm{LB}$ & $95 \%$ UB & $90 \% \mathrm{LB}$ & $90 \%$ UB \\
\hline 4.6564 & 3.0144 & 4.5077 & 2.4978 & 3.7886 \\
\hline $\mathrm{W}$-statistic & $95 \% \mathrm{LB}$ & $95 \%$ UB & $90 \% \mathrm{LB}$ & $90 \%$ UB \\
\hline 32.5949 & 21.0801 & 31.5538 & 17.4845 & 26.5202 \\
\hline
\end{tabular}

\section{Diagnostic Tests}

Serial Correlation, CHSQ(1) = 1.5857 [0.208]: Lagrange multiplier test of residual serial correlation

Functional Form, CHSQ(1) $=0.027928$ [0.867]: Ramsey's RESET test using the square of the fitted values

Normality, CHSQ(2) = 2.3570 [0.308] Not applicable: Based on a test of skewness and kurtosis of residuals

Heteroscedasticity, CHSQ(1) $=0.24858$ [0.618]: Based on the Regression of Squared Residuals on Squared Fitted Values

Source: Author's Computations using MICROFIT 5.5. Note: ${ }^{* *},{ }^{* *}$ and ${ }^{\star}$ denote $1 \%, 5 \%$ and $10 \%$ level of significance respectively. 
implication of the results is that if prudently managed the public sector can as well improve the performance. Second, improved sector governance, strong liberalization law, effective commercialization, competition and independent regulation are necessary for improved performance and attracting private investment sustainably (Figure 1).

\subsection{Reforms and Electricity Connectivity}

In our review, we have also uncovered that after the reforms the electricity connectivity had increased.

Table 5 depicts that the liberalization law and energy fund are statistically significant affecting the connectivity positively. The coefficients for privatization and competition are positive though not statistically significant. The results further show the coefficients independent regulation and commercialization are negative though not statistically significant. This suggests that the two policies exerted a negative influence on electricity connectivity. The overall results appear to concur with early findings (Eberhard \& Godinho, 2017; Dertinger \& Hirth, 2019).

The findings, however, seem to contradict previous research (Idris et al., 2013; Estache et al., 2009; Sihag et al., 2007) that the reforms do not improve connectivity. By 2019, about $37.7 \%$ of households in Tanzania were connected to electricity compared to $10 \%$ in 2005 . Interestingly, we found no significant correlation between the increase in connectivity with privatization as by 2020 , only two private companies, namely; Andoya and Mwenga with less than 2\% market share were supplying electricity to end-users. The outcome can be mainly connected to the operationalization of the Rural Energy Agency-REA in 2007 to promote access to modern energy in rural areas through grants. Its creation was aimed to address the failure of the government to extend access to rural areas.

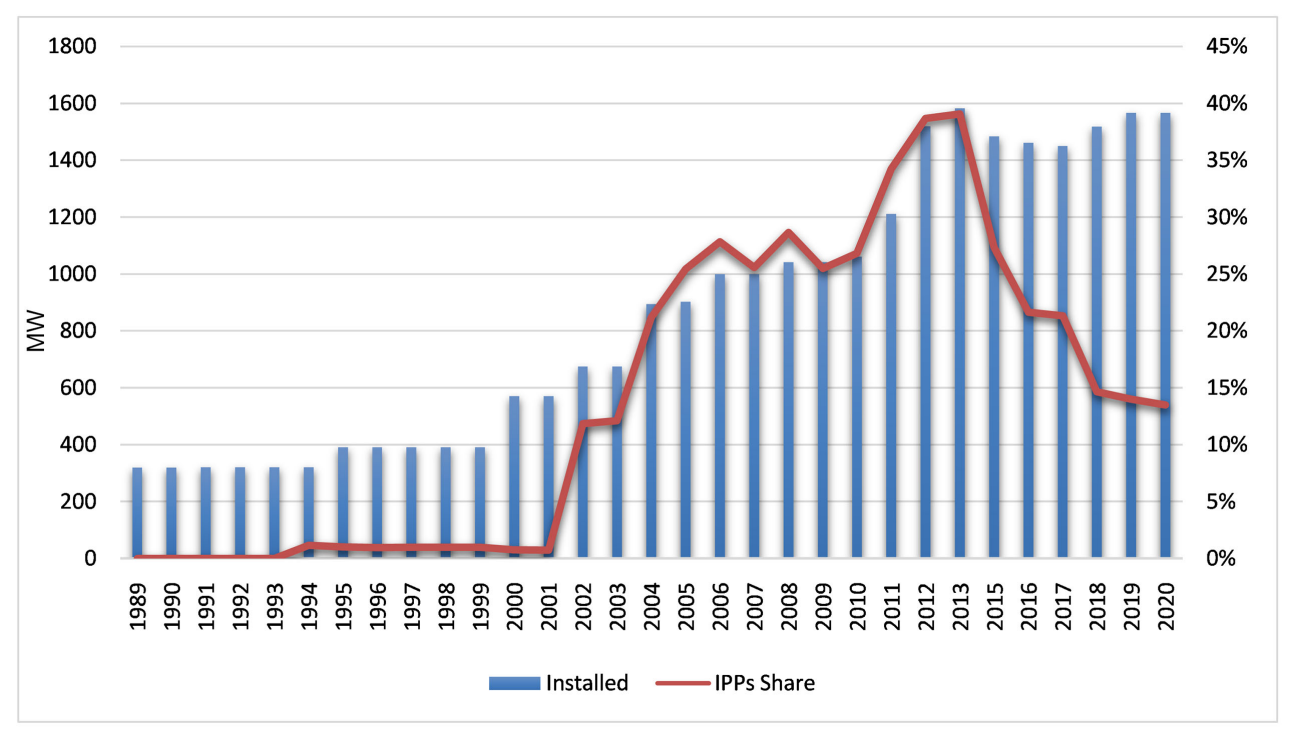

Figure 1. Capacity growth and private sector share. Source: Authors, 2021 based on data from TANESCO 1989-2020. 
Table 5. ARDL output for electricity connectivity.

\begin{tabular}{|c|c|c|c|c|}
\hline \multicolumn{5}{|c|}{29 Observations used for Estimation from 1989 to 2020} \\
\hline Regressor & Coefficient & Standard Error & T-Ratio & [Prob.] \\
\hline $\mathrm{EC}(-1)$ & 0.47624 & 0.13797 & 3.45180 & {$[0.003]^{* * *}$} \\
\hline LL & 0.03216 & 0.01454 & 2.21240 & {$[0.042]^{* *}$} \\
\hline $\mathrm{LL}(-1)$ & 0.03017 & 0.00907 & 3.32520 & {$[0.004]^{* * *}$} \\
\hline IR & -0.00462 & 0.01212 & -0.38102 & {$[0.708]$} \\
\hline $\mathrm{COM}$ & -0.00280 & 0.01003 & -0.27872 & {$[0.784]$} \\
\hline $\operatorname{COM}(-1)$ & 0.02296 & 0.01228 & 1.86910 & {$[0.080]^{*}$} \\
\hline $\operatorname{COM}(-2)$ & -0.02276 & 0.01283 & -1.77460 & {$[0.095]^{\star}$} \\
\hline $\mathrm{EF}$ & 0.02160 & 0.01024 & 2.10930 & {$[0.051]^{\star}$} \\
\hline $\mathrm{EF}(-1)$ & 0.01421 & 0.01312 & 1.08350 & [0.295] \\
\hline $\mathrm{EF}(-2)$ & -0.03855 & 0.01470 & -2.62300 & {$[0.018]^{* *}$} \\
\hline PRIV & 0.00787 & 0.01674 & 0.47005 & {$[0.645]$} \\
\hline COMP & 0.00270 & 0.01409 & 0.19134 & {$[0.851]$} \\
\hline CONSTANT & 0.02222 & 0.00821 & 2.70770 & {$[0.016]^{* *}$} \\
\hline R-Squared & 0.99174 & R-Bar-Squared & 0.98554 & \\
\hline S.E of Regression & 0.012672 & F-stat. F(17, 11) & 160 & \\
\hline Mean of Dep. Var. & 0.13604 & S.D of Dep.Var. & 0.10569 & \\
\hline RSS & 0.0025692 & Equat LL & 94.1569 & \\
\hline AIC & 81.1569 & SBC & 72.2695 & \\
\hline DW-statistic & 2.0438 & Durbi & $=-0.17621$ & \\
\hline F-statistic & $95 \% \mathrm{LB}$ & $95 \%$ UB & $90 \% \mathrm{LB}$ & $90 \% \mathrm{UB}$ \\
\hline 4.0623 & 3.0144 & 4.5077 & 2.4978 & 3.7886 \\
\hline $\mathrm{W}$-statistic & $95 \% \mathrm{LB}$ & $95 \%$ UB & $90 \% \mathrm{LB}$ & $90 \% \mathrm{UB}$ \\
\hline 28.4360 & 21.0801 & 31.5538 & 17.4845 & 26.5202 \\
\hline
\end{tabular}

\section{Diagnostic Tests}

Serial Correlation, CHSQ $(1)=0.031224\left[0.860{ }^{\star} \mathrm{F}(1,15)=0.016168[0.901]^{\star}\right.$ : Lagrange multiplier test of residual serial correlation

Functional Form, CHSQ $(1)=0.031224[0.860] * F(1,15)=0.016168[0.901]^{\star}$ : Ramsey's RESET test using the square of the fitted values

Normality, CHSQ $(2)={ }^{*} \mathrm{CHSQ}(2)=4.0107(0.135) *$ Not applicable: Based on a test of skewness and kurtosis of residuals Heteroscedasticity, CHSQ $(1)=2.3786[0.123] * \mathrm{~F}(1,27)=2.4124[0.132]^{\star}$ : Based on the Regression of Squared Residuals on Squared Fitted Values

Note: ${ }^{* \star},{ }^{* *}$ and ${ }^{\star}$ denote $1 \%, 5 \%$ and $10 \%$ level of significance. Source: Author's Computations using MICROFIT 5.5 .

Likewise, the increase can be linked to a political decision in 2013 to reduce connection charges between $29 \%$ and $75 \%$ to attain a $1,500,000$ customers connection target by 2015 . These initiatives were largely politically motivated which confirms the public choice theory assertion that while governments attempt to 
maximize some form of social welfare, they do so for themselves, to maximize votes. Despite the notable progress, by the year 2020 , only about $24.5 \%$ of the rural population accounting for $65 \%$ of the national population had access to electricity (NBS, 2020). The World Bank (2017) thus admits that regardless of the reforms, the sector in Tanzania still suffers from infrastructure deficits, low access particularly in rural areas, and weak financial condition. Figure 2 describes the electricity connectivity trends over time. Thus, the main policy implication of the results is that to deepen and accelerate access to electricity the government should step up more efforts to strengthen the energy fund and enact a strong liberalization law to open up the sector further to the private sector.

Overall, our empirical findings suggest that after the reforms capacity and electricity connectivity had improved though were largely sponsored by the government. The results accordingly add value to theoretically and empirically literature. The market-oriented institutional change theories were based on the assumption that private ownership and competition improve performance and maximize the welfare of society. But recent studies reveal that performance improvement is not merely a function of change in ownership. This study has contributed to the theoretical framework by revealing that if prudently managed and subjected to competition, the public sector has as well the potential of improving performance. Methodologically, most of the previous studies in Tanzania were qualitative in nature based on cross-country analysis. To the best of our knowledge, this is probably among the first country-specific studies to quantify the impact of reforms on performance using the ARDL model.

Empirically, the impact of the reforms on performance has been extensively studied but different scholars came up with different conclusions. This study, therefore, added value to the current literature by unleashing new insights about

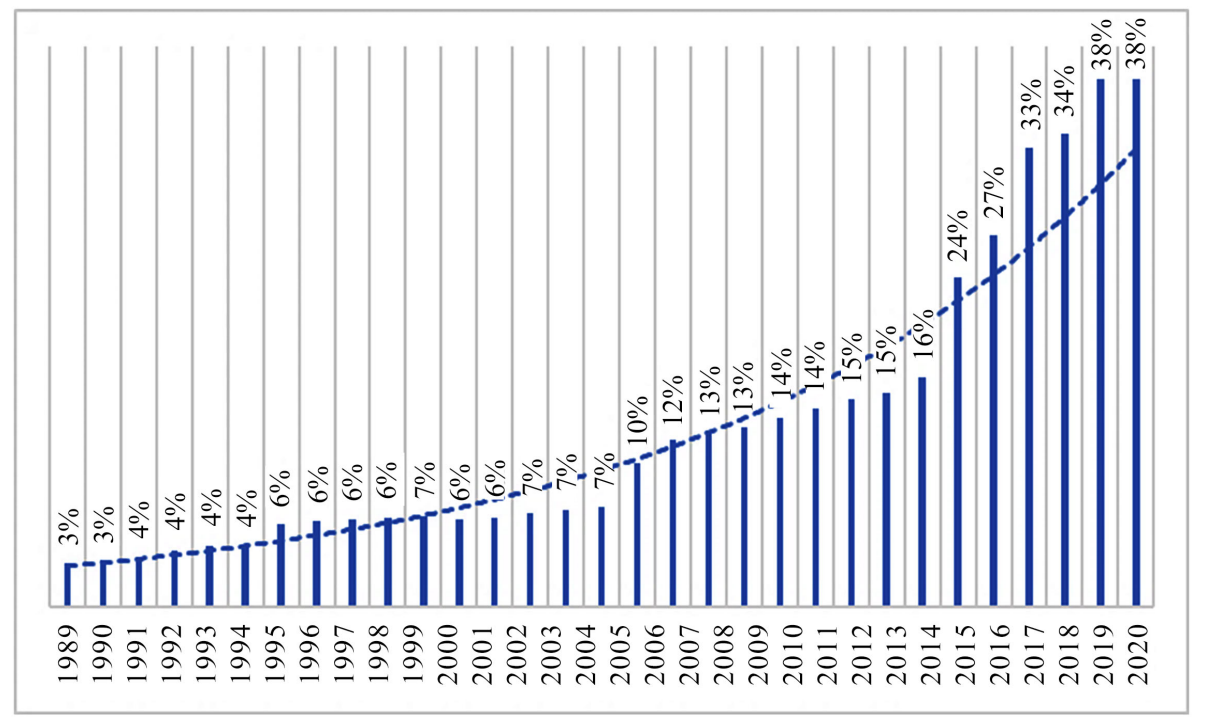

Figure 2. Electricity connectivity trends. Source: Authors, 2021 based on data from TANESCO 1989-2020. 
reform dynamics including the value of improved sectoral governance for improved performance. Practically, it is nearly two decades since Tanzania began the reforms. The outcomes however were not very well known as the phenomena were scantly studied. To the best of our knowledge, this is probably among the first comprehensive study to holistically quantify the impact of the reforms in Tanzania. The next section summarizes the main conclusion and policy implications.

\section{Conclusion and Recommendations}

This study investigated the impact of reforms on investment in Tanzania's power sector. Our empirical findings suggest that after reforms, capacity growth and electricity connectivity had improved. The improvement however was government-sponsored demonstrating that privatization is probably not a panacea to solving sectoral performance, increasing investment specifically. Limited private sector participation in the power sector may as well be associated with weak sector governance manifested by the politicization of the sector, weak institutions and incomplete reforms. These results point to numerous policy directions. First and as demonstrated by Norway, China, the EU, and Russia, the most important policy implication of the results is that the public sector also has the potential of improving the performance if prudently managed. This revelation diminishes the long-standing belief that considered the private sector to be inherently more efficient than the public sector.

Second, in this study, we uncovered that the liberalization law, competition, and commercialization as the reform policies were found to be statistically significant and positively affecting investment. Thus, regardless of ownership form, we recommend that the government prioritize these reform policies for improved investment in the sector. Third, rural access in Tanzania remains restricted (24.5\%). As a result, more investment is required to address energy poverty in rural areas. Because access to electricity remains limited, particularly in rural areas, to deepen and accelerate access to electricity, the government should step up more efforts to strengthen the energy fund and enact a strong liberalization law to open up the sector further to the private sector. Fourth, to bridge the infrastructure deficit and ensure long-term secure supply in most developing countries, investments from both the public and private sectors should be encouraged. The public sector will act as a supporter and/or competitor of the private sector and the private sector will complement governments' efforts. Above all, it is recommended that to achieve the first-best outcomes, policymakers should promote better sector governance explained by the strong institutions, high government commitment to reforms, predictable legal and regulatory frameworks.

The significance of these findings cannot be underrated as it extends beyond Tanzania to other countries struggling to formulate or reformulate their reform programs. Despite its significance, like most studies, this study had some limita- 
tions, such as a small dataset due to the short history of the reforms, limited analysis on the impact of reforms on societal welfare, and inadequate benchmarking of reform progress against neighbouring countries. As a result, as more data becomes available, more research along these spectrums may be conducted in the future.

\section{Acknowledgements}

I would like to thank my co-author, Dr. Saganga of the Open University of Tanzania for his fruitful comments and suggestions. Further, I express my deepest gratitude to Dr. Nicas Yabu for his support and insightful comments on a previous version of this paper. Any remaining errors belong entirely to the author. The usual disclaimer applies.

\section{Funding}

The research is self-financed by the corresponding author as part of his $\mathrm{PhD}$ project.

\section{Conflicts of Interest}

The authors declare no conflicts of interest regarding the publication of this paper.

\section{References}

Albadi, M. H. (2017). Electricity Sector in Oman after 10 Years of Reforms: Status, Trends and Future Perspectives. The Electricity Journal, 30, 23-30. https://doi.org/10.1016/j.tej.2017.07.005

Aminu, A., Peterside, I. S., \& Brown, Z. (2014). The Impact of Privatization of Power Sector in Nigeria: A Political Economy Approach. Mediterranean Journal of Social Sciences, 5, 111-118. https://doi.org/10.5901/mjss.2014.v5n26p111

Ashong, M. (2010). Continuing Power Sector Reform Amidst High-Cost Power Generation Versus the Need to Protect Consumers from Increasing Tariffs, What Should Be the Way Forward for Ghana after over a Decade since New Policy Reforms Were Introduced? CEPMLP Annual Review.

Balza, L., Jimenez, R., \& Mercado, J. (2013). Privatization, Institutional Reform, and Performance in the Latin American Electricity Sector, Inter-American Development Bank. Technical Note, No. IDB-TN-599.

Bastos, C., \& Abdala, M. A. (1996). Reform of Electricity Power Sector in Argentina, Buenos Aires.

Bergara, M., Henisz, W. J., \& Spiller, P. T. (1998). Political Institutional and Electric Utility Investment: A Cross-Nation Analysis, Program on Workable Energy Regulation (POWER). California Management Review, 40, 18-35.

https://doi.org/10.2307/41165931

Besant-Jones, J. E. (2006). Reforming Power Markets in Developing Countries: What Have We Learned? Energy and Mining Sector Board Discussion Paper No. 19, September, The World Bank Group.

Bhattacharyya, S. C. (2006). Energy Access Problem of the Poor in India: Is Rural Electri- 
fication a Remedy? Energy Policy, 34, 3387-3397.

https://doi.org/10.1016/j.enpol.2005.08.026

Cubbin, J., \& Stern, J. (2006). The Impact of Regulatory Governance and Privatization on Electricity Industry Generation Capacity in Developing Economies. The World Bank Economic Review, 20, 115-141. https://doi.org/10.1093/wber/lhj004

Davies, L., Wright, K., \& Price, C. A. (2006). Experience of Privatisation, Regulation, and Competition: Lessons for Governments. ESRC Centre for Competition Policy, University of East Anglia. https://doi.org/10.2139/ssrn.911561

Dertinger, A., \& Hirth, L. (2019). Reforming the Electric Power Industry in Developing Economies. ZBW-Leibniz Information Centre for Economics.

Eberhard, A., \& Godinho, C. (2017). A Review and Exploration of the Status, Context and Political Economy of Power Sector the reform in Sub-Saharan Africa, South Asia, and Latin America. MIR Working Paper, University of Cape Town.

Erdogdu, E. (2013). A Cross-Country Analysis of Electricity Market Reforms: Potential Contribution of New Institutional Economics. Energy Economics, 39, 239-251.

https://doi.org/10.1016/j.eneco.2013.05.012

Erdogdu, E. (2014). Essays on Electricity Market Reforms: A Cross-Country Applied Approach. Ph.D. Thesis, University of Cambridge.

Estache, A., Goicoechea, A., \& Trujillo, L. (2009). Utilities Reforms and Corruption in Developing Countries. Utilities Policy, 17, 191-202.

https://doi.org/10.1016/j.jup.2008.07.002

Fisher, R., Gutierrez, R., \& Serra, P. (2004). The Effects of Privatization on Firms and Social Welfare: The Chilean Case. Research Network Working Paper No. 456 (May), Latin America Research Network, Inter-American Development Bank.

https://doi.org/10.2139/ssrn.1814714

Godinho, C., \& Eberhard, A. (2018). Power Sector Reform and Regulation in TanzaniaTanzania Institutional Diagnostic. WP18/TID07 Economic Development and Institutions.

Govinda, R. T., Jamasb, \& Nepal, R. (2015). Electricity Sector Reform in Developing Countries: A Survey of Empirical Evidence on Determinants and Performance.

Gratwick, K. N., \& Eberhard, A. (2008). An Analysis of Independent Power Projects in Africa: Understanding Development and Investment Outcomes. Development Policy Review, 26, 309-338. https://doi.org/10.1111/j.1467-7679.2008.00412.x

Hall, D., \& Nguyen, T. A. (2017). Electricity Liberalization in Developing Countries. Sage Journals, 17, 1-35. https://doi.org/10.1177/1464993416688824

Idris, A., Kura, M. S., Ahmed, A. M., \& Abba, Y. (2013). An Assessment of the Power Sector Reform in Nigeria. International Journal of Advancements in Research and Technology, 2, 20-37.

IMF (2016). Power It Up: Strengthening the Electricity Sector to Improve Efficiency and Support Economic Activity. IMF Working Paper, IMF.

Jamasb, T., Mota, R., Newberry, D., \& Pollitt, M. (2005). Electricity Sector Reform in Developing Countries: A Survey of Empirical Evidence on Determinants and Performance. World Bank Policy Research Working Paper 3549, World Bank. https://doi.org/10.1596/1813-9450-3549

Jamasb, T., Nepal, R., Timilsina, G., \& Michael, T. (2014). Energy Sector Reform, Economic Efficiency and Poverty Reduction. The World Bank.

Jamasb, T., Nepal, R., \& Timilsina, G. (2015). A Quarter Century Effort Yet to Come of Age: 
A Survey of Power Sector Reforms in Developing Countries. Policy Research Working Paper Series 7330, The World Bank, Washington DC.

https://doi.org/10.1596/1813-9450-7330

Jamasb, T., Sen, A., \& Nepal, R. (2016). Reforming Electricity the Reform: Empirical Evidence from Non-OECD Asian Economies (pp. 1-45). Oxford Institute for Energy Studies.

Kapika, J., \& Eberhard, A. (2010). Assessing Regulatory Performance: The Case of the Namibian Electricity Supply Industry, Graduate School of Business. Journal of Energy in Southern Africa, 21, 7-14. https://doi.org/10.17159/2413-3051/2010/v21i4a3258

Karekezi, S., \& Kimani, J. (2002). Status of Power Sector Reform in Africa: Impact on the Poor. Energy Policy, 30, 923-945. https://doi.org/10.1016/S0301-4215(02)00048-4

Lee, D. A., \& Usman, Z. (2018). Taking Stock of the Political Economy of Power Sector the Reform in Developing Countries. Policy Research Working Paper 8518, World Bank. https://doi.org/10.1596/1813-9450-8518

Mayson, S. (2013). Legal Services and Regulation and the Public Interest. Wordpress.com.

Mwandosya, J. M. (2013). Uthibiti wa Huduma za Kiuchumi Tanzania. E and D Vision Publishing.

NBS (2020). Energy Access and Use Situation Survey in Tanzania Mainland, Summary of Key Findings. National Bureau of Statistics.

Nepal, R. (2013). From State to Market: Essays on Electricity Sector Reforms. PhD Thesis, Heriot-Watt University.

Nepal, R., \& Foster, J. (2015). Electricity Networks Privatization in Australia: An Overview of the Debate. Charles Darwin University, School of Business.

Parker, D., Kirkpatric, C., \& Zhang, Y. (2002). Electricity Sector Reform in Developing Countries: An Econometric Assessment of the Effects of Privatisation, Competition and Regulation. Working Paper No. 31, Institute for Development Policy and Management, University of Manchester, Manchester.

Polemis, M. L. (2016). New Evidence on the Impact of Structural Reforms on Electricity Sector Performance. Energy Policy, 92, 3-12. https://doi.org/10.1016/j.enpol.2016.02.032

Quiggin, J. (2014). Electricity Privatization in Australia: A Record of Failure, the Victoria Branch of the Electrical Trade Union, Australia.

Sen, A., Nepal, R., \& Jamasb, T. (2016). Have Model, Will Reform: Assessing the Outcomes of Electricity Reforms in Non-OECD Asia. The Energy Journal, 39, 181-210. https://doi.org/10.5547/01956574.39.4.asen

Siami-Namini, S. (2017). Reverse Privatization and New Government Reforms: A Review of Theory and Evidence. International Journal of Current Advanced Research, 6, 68466856.

Sihag, A., Mishra, R., \& Sharma, N. V. (2007). Impact of Power Sector Reform on Poor: A Case Study of South and South East Asia. Tata Energy Research Institute.

Smith, A. (1776). An Inquiry into the Nature and Causes of the Wealth of Nations. W. Strahan and T. Cadell, London. https://doi.org/10.1093/oseo/instance.00043218

Tankha, S. (2017). From Market to Plan: Lessons from Brazilian Power Reforms on Reducing Risks in the Provision of Public Services. Policy and Society.

Victor, D., \& Heller, T. C. (2008). The Political Economy of Power Sector Reforms: The Experiences of Five Major Developing Countries. Cambridge University Press. https://doi.org/10.1017/CBO9780511493287 
Wooders, P., Bridle, R., \& Nguyen, T. C. (2014). A Financially Sustainable Power Sector: Developing Assessment Methodologies. The International Institute for Sustainable Development.

World Bank (2009). Monitoring Performance of Electric Utilities: Indicators and Benchmarking in Sub-Saharan Africa. The Energy Sector Management Assistance Program, The World Bank.

World Bank (2011). Revisiting Policy Options on the Market Structure in the Power Sector. The Energy Sector Management Assistance Program, World Bank.

World Bank (2017). United Republic of Tanzania Systematic Country. World Bank.

Yang, J., \& Urpelainen, J. (2019). Global Patterns of Power Sector Reform, 1982-2013, Energy Strategies Reviews, 23, 152-162. https://doi.org/10.1016/j.esr.2018.12.001

Zhang, Y. F., Parker, D., \& Kirkpatrick, C. (2005). Competition, Regulation, and Privatisation of Electricity Generation in Developing Countries: Does the Sequencing of Reforms Matter? Journal of Regulatory Economics, 33, 159-178.

Zhang, Y., Parker, D., \& Kirkpatrick, C. (2008). Electricity Sector Reform in Developing Countries: An Econometric Assessment of the Effects of Privatization, Competition, and Regulation. Journal of Regulatory Economics, 33, 159-178.

https://doi.org/10.1007/s11149-007-9039-7 


\section{Appendix 1. Reforms Status in Tanzania}

\begin{tabular}{|c|c|c|c|}
\hline Year Policy Dimension & Key Features & Status: Tanzania & Remarks \\
\hline $1992 \begin{array}{l}\text { Independent Power } \\
\text { producers }\end{array}$ & $\begin{array}{l}\text { Independent power producers (IPPs) are } \\
\text { private companies that participate in power } \\
\text { generation for sale to end-users or SOUs. } \\
\text { They are introduced as the quickest way to } \\
\text { increase the installed capacity, private } \\
\text { investment, and competition in the sector } \\
\text { and unburden governments from funding } \\
\text { the new power plants }\end{array}$ & $\begin{array}{l}\checkmark \text { In } 1992 \text { the national energy policy passed } \\
\text { lifting TANESCO's monopoly in power } \\
\text { generation and distribution segments. } \\
\checkmark \text { In } 1993 \text { bids for IPPs tendered leading to the } \\
\text { entry of IPTL-103 MW ( } 2002 \text { online) and } \\
\text { Songas -189 MW (2004). }\end{array}$ & Introduced \\
\hline 1993 Commercialization & $\begin{array}{l}\text { Commercialization entails observing the } \\
\text { norms of the private sector of operating for } \\
\text { profit, maximizing efficiency, moving to } \\
\text { full-cost recovery, introducing cost-cutting } \\
\text { measures, reducing staff, reducing or } \\
\text { removing subsidies, and enforcing } \\
\text { collections of electricity bills. }\end{array}$ & $\begin{array}{l}\checkmark \text { Initiated in } 1993 \text { under the World Bank VI } \\
\text { Project where tariffs were modestly increased } \\
\text { and prepaid meters introduced } \\
\checkmark \text { Accelerated during the Net Group } \\
\text { Solutions, and in } 2010-2013 \text { when EPPs } \\
\text { were procured. } \\
\checkmark \text { Officially promoted from } 2006 \text { when } \\
\text { EWURA became operational. }\end{array}$ & Introduced \\
\hline 1995 Competitive markets & $\begin{array}{l}\checkmark \text { Competition is an ordering force that } \\
\text { ensures efficient allocation of resources, } \\
\text { promotes rivalry between suppliers, and } \\
\text { eliminates excessive profit. } \\
\checkmark \text { It involves the provision of electric service } \\
\text { by two or more rival entities in the same } \\
\text { service area whereas the owners of } \\
\text { monopoly infrastructure provide equal } \\
\text { access to new entrants (competitors) on } \\
\text { commercial terms similar to what would } \\
\text { exist in a competitive market. }\end{array}$ & $\begin{array}{l}\checkmark \text { In } 1995 \text { the single buyer model was } \\
\text { introduced where TANESCO enters PPAs } \\
\text { with IPPs. Bilateral agreements as well exist } \\
\text { where IPPs sell directly to the bulk-off taker. } \\
\text { The commencement of IPTL power } \\
\text { generation in the } 2002 \text { market. } \\
\checkmark \text { In } 2016 \text {, the Regulations promoting } \\
\text { competition and guaranteeing equal } \\
\text { access to monopoly infrastructure were } \\
\text { released. } \\
\checkmark \text { The first PPA was entered in 1995. IPTL } \\
\text { became commercially operational in } 2002 \text {. In } \\
2016 \text { the bilateral agreement between } \\
\text { Dangote Group Industries and Jinan Diesel } \\
\text { Engine Co. was Ltd was signed. Small Power } \\
\text { Independent Distributors Producers such as } \\
\text { Mwenga Power Services Limited and } \\
\text { Andoya Hydro Electric Power Company } \\
\text { Limited }\end{array}$ & Introduced \\
\hline
\end{tabular}




\section{Continued}

\begin{tabular}{|c|c|c|c|}
\hline 1997 Privatization & $\begin{array}{l}\text { Private investors are allowed to invests in } \\
\text { the sector previously under state monopoly. } \\
\text { It includes the transfer of public property or } \\
\text { business to a private entity through outright } \\
\text { sale of assets, joint venture, or disposal of } \\
\text { shares in the stock market; outsourcing } \\
\text { operations to a private firm for a specific } \\
\text { period (concessions agreement); involving } \\
\text { the private sector in management } \\
\text { (management and lease contracts); and } \\
\text { constructing new projects that are either } \\
\text { entirely private or a public-private } \\
\text { partnership; deregulation of the sector. }\end{array}$ & $\begin{array}{l}\checkmark 1997 \text { TANESCO was specified for } \\
\text { privatization though the decision was } \\
\text { reversed in } 2005 \\
\checkmark \text { In } 2001 \text { the } 112 \text { MW power plant and } \\
\text { Songo-Songo gas facilities were privatized to } \\
\text { Songas } \\
\checkmark \text { In } 2003 \text {, a concession was awarded to } \\
\text { Artumas Group to supply power to Mtwara } \\
\text { and Lindi Regions. } \\
\checkmark \text { Between } 2002-2005 \text { TANESCO was under the } \\
\text { private management of NetGroup Solutions } \\
\text { from South Africa. }\end{array}$ & Introduced \\
\hline 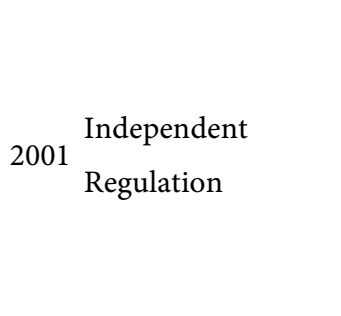 & $\begin{array}{l}\text { Independent regulation involves separating } \\
\text { the regulatory roles from the government } \\
\text { bodies and granting the new organ the right } \\
\text { and freedom to decide on regulatory } \\
\text { matters without prior consent from the } \\
\text { government. }\end{array}$ & $\begin{array}{l}\checkmark \text { Energy and Water Utilities Regulatory } \\
\text { Authority (EWURA) to regulate electricity, } \\
\text { waters and natural gas, and petroleum } \\
\text { downstream segment. }\end{array}$ & Introduced \\
\hline 2002 Corporatization & $\begin{array}{l}\checkmark \text { Corporatization is transforming a utility } \\
\text { company into an independent legal entity } \\
\text { governed by the principles of corporate } \\
\text { law such as greater operational } \\
\text { autonomy, clear commercial objectives } \\
\text { and performance targets, effective } \\
\text { monitoring systems; and a high degree of } \\
\text { financial independence and transparency. } \\
\checkmark \text { Separate utility from ministry, create a } \\
\text { clear accounting framework and provide } \\
\text { greater operational autonomy. }\end{array}$ & $\begin{array}{l}\checkmark \text { In } 1931 \text { the Electricity Ordinance established } \\
\text { two quasi-private companies: DARESCO and } \\
\text { TANESCO which were merged in } 1964 \text {. } \\
\checkmark \text { In } 1975 \text { the government acquired EPLC’s } \\
\text { shares in TANESCO. } \\
\checkmark \text { In } 2002 \text { the incumbent TANESCO was } \\
\text { officially corporatized under the Companies } \\
\text { Act of } 2002 \text { clarifying its mandates against the } \\
\text { parent ministry. }\end{array}$ & Introduced \\
\hline $\begin{array}{l}2005 \text { Rural Energy Fund } \\
\text { and Agency }\end{array}$ & $\begin{array}{l}\checkmark \text { Commercial and Non-commercial } \\
\text { electrification expansion are separated } \\
\text { from the commercial left under the utility } \\
\text { mandates. } \\
\checkmark \text { The fund helps to speed up access to } \\
\text { modern energy in rural areas where the } \\
\text { private sector is unable or unwilling to } \\
\text { invest due to economic and technical } \\
\text { constraints. }\end{array}$ & $\begin{array}{l}\checkmark \text { In } 2005 \text { the legislation to form the Rural } \\
\text { Energy Agency and Rural Energy Fund was } \\
\text { passed to facilitate the electrification of the } \\
\text { non-commercial segment passed. } \\
\checkmark 2007 \text { REA became operational }\end{array}$ & Introduced \\
\hline
\end{tabular}




\section{Continued}

\begin{tabular}{|c|c|c|c|}
\hline \multirow{11}{*}{2008 Liberalization Law } & & $\checkmark$ In 2008 Electricity Act was enacted & \multirow{11}{*}{ Introduced } \\
\hline & $\checkmark$ Involves legal mandate restructuring & liberalizing the entire power supply chain & \\
\hline & and permitting the private sector & including reform intentions but with some & \\
\hline & participation/ownership/imports in the & prohibitive clauses. & \\
\hline & sector. & $\checkmark$ Presently, there as private investors in the & \\
\hline & $\checkmark$ A good law normally commercializes the & form IPPs, Small Power Producers (SPPs), & \\
\hline & electrical service by encouraging & Independent Power Distributors (IPD), and & \\
\hline & cost-reflective tariffs, criminalizes power & Self-generators (own use). & \\
\hline & theft, and insulates the sector from & \multirow{3}{*}{$\begin{array}{l}\checkmark \text { In } 2015 \text { section } 41(6) \text { of the Electricity Act } \\
\text { that prevented IPPs from selling electricity to } \\
\text { end-users lifted. }\end{array}$} & \\
\hline & political interventions. & & \\
\hline & & & \\
\hline \multirow{11}{*}{ Unbundling } & Unbundling entails breaking up a vertically & \multirow{11}{*}{$\begin{array}{l}\checkmark \text { Plans for unbundling TANESCO remains a } \\
\text { goal since the } 1990 \text { s }\end{array}$} & \multirow{11}{*}{$\begin{array}{l}\text { Not } \\
\text { introduced }\end{array}$} \\
\hline & integrated state monopoly company into & & \\
\hline & multiple power generation and distribution & & \\
\hline & companies that trade each other & & \\
\hline & competitively, raise capital from the capital & & \\
\hline & markets and pay dividends and taxes to & & \\
\hline & governments. & & \\
\hline & Vertical and/or horizontal unbundling, & & \\
\hline & create independent transmission company, & & \\
\hline & separate profitable parts for sale to private & & \\
\hline & investors. & & \\
\hline
\end{tabular}

Source: Compiled by the Researcher, 2019 from the Literature review. 